\title{
Organic, elemental and inorganic carbon in particulate matter of six urban environments in Europe
}

\author{
M. Sillanpää ${ }^{1}$, A. Frey ${ }^{1}$, R. Hillamo ${ }^{1}$, A. S. Pennanen ${ }^{2}$, and R. O. Salonen ${ }^{2}$ \\ ${ }^{1}$ Finnish Meteorological Institute, Air Quality Research, Erik Palménin aukio 1, FIN-00560 Helsinki, Finland \\ ${ }^{2}$ National Public Health Institute, Department of Environmental Health, Neulaniementie 4, FIN-70210 Kuopio, Finland \\ Received: 17 February 2005 - Published in Atmos. Chem. Phys. Discuss.: 3 May 2005 \\ Revised: 14 September 2005 - Accepted: 19 October 2005 - Published: 2 November 2005
}

\begin{abstract}
A series of 7-week sampling campaigns were conducted in urban background sites of six European cities as follows: Duisburg (autumn), Prague (winter), Amsterdam (winter), Helsinki (spring), Barcelona (spring) and Athens (summer). The campaigns were scheduled to include seasons of local public health concern due to high particulate concentrations or findings in previously conducted epidemiological studies. Aerosol samples were collected in parallel with two identical virtual impactors that divide air particles into fine $\left(\mathrm{PM}_{2.5}\right)$ and coarse $\left(\mathrm{PM}_{2.5-10}\right)$ size ranges. From the collected filter samples, elemental (EC) and organic (OC) carbon contents were analysed with a thermaloptical carbon analyser (TOA); total $\mathrm{Ca}, \mathrm{Ti}, \mathrm{Fe}, \mathrm{Si}, \mathrm{Al}$ and $\mathrm{K}$ by energy dispersive X-ray fluorescence (ED-XRF); As, $\mathrm{Cu}, \mathrm{Ni}, \mathrm{V}$, and $\mathrm{Zn}$ by inductively coupled plasma mass spectrometry (ICP/MS); $\mathrm{Ca}^{2+}$, succinate, malonate and oxalate by ion chromatography (IC); and the sum of levoglucosan+galactosan+mannosan ( $(\mathrm{MA})$ by liquid chromatography mass spectrometry (LC/MS). The campaign means of $\mathrm{PM}_{2.5}$ and $\mathrm{PM}_{2.5-10}$ were $8.3-29.6 \mu \mathrm{g} \mathrm{m}^{-3}$ and 5.4$28.7 \mu \mathrm{g} \mathrm{m}^{-3}$, respectively. The contribution of particulate organic matter (POM) to $\mathrm{PM}_{2.5}$ ranged from $21 \%$ in Barcelona to $54 \%$ in Prague, while that to $\mathrm{PM}_{2.5-10}$ ranged from $10 \%$ in Barcelona to $27 \%$ in Prague. The contribution of EC was higher to $\mathrm{PM}_{2.5}$ (5-9\%) than to $\mathrm{PM}_{2.5-10}(1-6 \%)$ in all the six campaigns. Carbonate $\left(\mathrm{C}\left(\mathrm{CO}_{3}\right)\right.$, that interferes with the TOA analysis, was detected in $\mathrm{PM}_{2.5-10}$ of Athens and Barcelona but not elsewhere. It was subtracted from the OC by a simple integration method that was validated. The $\mathrm{CaCO}_{3}$ accounted for $55 \%$ and $11 \%$ of $\mathrm{PM}_{2.5-10}$ in Athens and Barcelona, respectively. It was anticipated that combustion emissions from vehicle engines affected the POM con-
\end{abstract}

Correspondence to: M. Sillanpää

(markus.sillanpaa@fmi.fi) tent in $\mathrm{PM}_{2.5}$ of all the six sampling campaigns, but a comparison of mass concentration ratios of the selected inorganic and organic tracers of common sources of organic material to POM suggested also interesting differences in source dominance during the campaign periods: Prague (biomass and coal combustion), Barcelona (fuel oil combustion, secondary photochemical organics) and Athens (secondary photochemical organics). The on-going toxicological studies will clarify the health significance of these findings.

\section{Introduction}

Urban aerosol is a complex mixture of primary particulate emissions (from industry, transportation, power generation and natural sources) and secondary material formed by gasto-particle conversion mechanisms. Urban aerosol contains a substantial amount of carbonaceous material (20-80\%; Rogge et al., 1993 and Nunes and Pio, 1993) that is composed of two main fractions: 1) elemental carbon (EC; sometimes referred to as black carbon or graphitic carbon) is a primary pollutant formed in combustion processes, and 2) particulate organic matter (POM) is a complex mixture of different groups of compounds originating from a large variety of processes (Seinfeld and Pandis, 1998).

Recent epidemiological studies have shown consistent associations of mass concentration of urban air thoracic particles $\left(\mathrm{PM}_{10}-50 \%\right.$ cutoff point at $\left.10 \mu \mathrm{m}\right)$, and its subfraction fine particles $\left(\mathrm{PM}_{2.5}-50 \%\right.$ cutoff point at $\left.2.5 \mu \mathrm{m}\right)$, with mortality and morbidity among cardiorespiratory patients (WHO, 2003). There are still relatively few epidemiological studies with detailed chemical speciation of the collected particulate samples, but one recent US time-series study (Metzger et al., 2004) has reported that the EC and

(C) 2005 Author(s). This work is licensed under a Creative Commons License. 
POM concentrations in $\mathrm{PM}_{2.5}$ were significantly associated with emergency department visits in hospitals due to cardiovascular diseases. It is known on the basis of experimental studies that the EC causes tissue irritation and a release of toxic chemical intermediates from scavenger cells in laboratory studies as well as acts as a carrier of various organic compounds. Moreover, volatile and semi-volatile organic, particulate-bound compounds can act as irritants and allergens. Many aromatic compounds are suspected mutagens and carcinogens and some them may also cause acute health effects (Lighty et al., 2000).

In this study, we report the mass concentrations of fine $\left(\mathrm{PM}_{2.5}\right)$ and coarse $\left(\mathrm{PM}_{2.5-10}\right)$ particles as well as their EC and POM contents from six geographically and seasonally contrasting particulate sampling campaigns in Europe. The campaigns were scheduled to include seasons of local public health concern due to high particulate concentrations or findings in previously conducted epidemiological studies. A specific objective of our work was to characterise the differences in concentration patterns as well as sources of the $\mathrm{EC}$ and POM between the sampling campaigns. Moreover, a new integration method was validated for subtraction of carbonate $\left(\mathrm{C}\left(\mathrm{CO}_{3}\right)\right)$ from the thermograms of the thermaloptical carbon analysis.

\section{Experimental methods}

\subsection{Sampling sites}

A series of 7-week sampling campaigns were conducted in six European cities. The sampling sites were located in urban background areas and were influenced by a variable contribution of traffic depending on the density of short-haul motor vehicles and the site topography. The sites are described in detail including the additional local emission sources of particles:

Duisburg $\left(51^{\circ} 26^{\prime} \mathrm{N}, 6^{\circ} 45^{\prime} \mathrm{E}\right)$. The sampling site was located near the city centre at a distance of $280 \mathrm{~m}$ from the nearest major street. The site was surrounded by three to five-storey buildings. The major local emission sources were road traffic (e.g. diesel trucks) and metal industry. The sampling campaign was conducted between 4 October and 21 November 2002 (autumn) when the mean \pm SD ambient temperature and total precipitation were $9 \pm 3^{\circ} \mathrm{C}$ and $90 \mathrm{~mm}$.

Prague $\left(50^{\circ} 5^{\prime} \mathrm{N}, 14^{\circ} 26^{\prime} \mathrm{E}\right)$. The sampling site was located in an open field of the Czech Hydrometeorological Institute in an uptown residential area. The nearest road at a distance of $150 \mathrm{~m}$ had a relatively low average traffic density of 5000 vehicles/day, while the nearest major road was at a distance of $1 \mathrm{~km}$. Road traffic, domestic heating with solid fuels and energy production were considered as the main local emission sources. The particulate samplings were carried out between 29 November 2002 and 16 January 2003 (winter) with prevailing ambient temperature of $-2 \pm 5^{\circ} \mathrm{C}$ and total precipitation of $50 \mathrm{~mm}$.

Amsterdam $\left(52^{\circ} 21^{\prime} \mathrm{N}, 4^{\circ} 54^{\prime} \mathrm{E}\right)$. The site was located near the city centre at a distance of $50 \mathrm{~m}$ from the nearest major street with an average traffic volume of 10000 vehicles/day. The site was surrounded by multi-storey buildings. Road and ship traffic were considered as the main local emission sources. The sampling campaign was conducted between 24 January and 13 March 2003 (winter) when the ambient temperature and total precipitation were $4 \pm 4^{\circ} \mathrm{C}$ and $60 \mathrm{~mm}$.

Helsinki $\left(60^{\circ} 10^{\prime} \mathrm{N}, 24^{\circ} 58^{\prime} \mathrm{E}\right)$. The site was located near the city centre at a distance of $300 \mathrm{~m}$ from the nearest major street with an average traffic volume of 30700 vehicles/day. The site had multi-storey buildings on one side but faced an open sports field on the other side. Road traffic and ships in the city harbour were considered as the main local emission sources. The particulate samplings were carried out between 21 March and 12 May 2003 (spring) with prevailing ambient temperature of $4 \pm 5^{\circ} \mathrm{C}$ and total precipitation of $48 \mathrm{~mm}$.

Barcelona $\left(41^{\circ} 23^{\prime} \mathrm{N}, 2^{\circ} 9^{\prime} \mathrm{E}\right)$. The site was located on a car park near the city centre. The nearest major road at a distance of $100 \mathrm{~m}$ had an average traffic density of 17000 vehicles/day. On one side, there was a multi-storey building and the canopy of a railway station whilst on the other side there was a park enclosing a zoo. Road traffic and ships in the large harbour, and to some extent the zoo, were considered as the main local emission sources. The sampling campaign was conducted between 28 March and 19 May 2003 (spring) when the ambient temperature and total precipitation were $15 \pm 2^{\circ} \mathrm{C}$ and $10 \mathrm{~mm}$.

Athens $\left(37^{\circ} 58^{\prime} \mathrm{N}, 23^{\circ} 43^{\prime} \mathrm{E}\right)$. The site was located near the city centre at a distance of $100 \mathrm{~m}$ from the nearest major road with an average traffic density of 30000 vehicles/day. The site was spaciously enclosed by three- or four-storey buildings. Road traffic, and to some extent construction work, were considered as the main local emission sources. The particulate samplings were carried out between 2 June and 21 July 2003 (summer) with prevailing ambient temperature of $29 \pm 4^{\circ} \mathrm{C}$ and total precipitation of $0 \mathrm{~mm}$.

The sampling duration was $3+4$ days per week, with filter exchange usually on Mondays and Thursdays between 10:00 and 12:00 a.m. The general protocol of the PAMCHAR field campaign necessitated to choose these relatively long samplings due to a parallel sampling of large, size-fractionated particulate samples for toxicological cell and animal studies, using a high-volume cascade impactor (Sillanpää et al., 2003). The total number of particulate samplings was 14 in each city. An automatic valve, that was programmed to switch on and off in cycles of $15 \mathrm{~min}$, was installed into the pump line of virtual impactors (VI) in Barcelona and Athens to avoid overloading of the filters. 


\subsection{Aerosol sampling instruments}

The aerosol particulate samples were collected in parallel with two VIs that divide the particulate matter into two size ranges: $\mathrm{PM}_{2.5}$ and $\mathrm{PM}_{2.5-10}$ (Loo and Cork, 1988). The total sampling flow rates of the VIs were $16.71 \mathrm{~min}^{-1}$ and the upper cut-off of the coarse particles was made with a low volume $\mathrm{PM}_{10}$-inlet similar to the design of Liu and Pui (1981). The particles were collected on polytetrafluoroethylene (PTFE) filters (diameter $47 \mathrm{~mm}$, pore size $3 \mu \mathrm{m}$, type FS, Millipore, Ireland) for gravimetric and chemical analysis, and on preheated quartz fibre filters (Pallflex Tissuquartz 2500QAT-UP) for carbon analysis. In the latter VI, a tandem filter collection method (two quartz fibre filters from the same lot in series) was applied for estimation and correction of positive sampling artefacts, i.e. an adsorption of organic gases. In practice, the OC value of backup filter was subtracted from that of front filter. The positive artefact correction has been performed to all the POM results presented in this study.

\subsection{Gravimetric and chemical analysis}

After sampling, the filters were placed on petrislides and those containing the quartz fibre filters were wrapped inside aluminium foil. All the samples were frozen and sent via express delivery service to the central laboratory of the project at the Finnish Meteorological Institute for gravimetric measurements and chemical analysis.

The PTFE filters were weighed with the same Mettler M3microbalance (Mettler Instrumente AG, Zurich, Switzerland) before and after sampling. The samples were allowed to stabilize in the weighing room for 15-60 min before weighing, which was shown in separate experiments to be sufficient for both clean and loaded PTFE filters. A criterion for valid weighing was that duplicate mass readings were within $2 \mu \mathrm{g}$ from each other. The mean \pm SD relative humidity $(\mathrm{RH})$ and temperature in the weighing room were $22 \pm 7 \%$ and $23 \pm 2{ }^{\circ} \mathrm{C}$, respectively, with the exception of $\mathrm{RH}$ being $49 \pm 8 \%$ during weighing the Barcelona and Athens samples. Regardless of different $\mathrm{RH}$, the deliquescence points of the abundant inorganic atmospheric salts were reached neither at $22 \%$ nor at $49 \%$ (Seinfeld and Pandis, 1998), because the filter samples (stored as frozen) were first melted on closed petrislides and subsequently stabilized at the prevailing condition of the weighing room. The scale and reading of the microbalance were checked daily with internal and standard weights. The electrostatic charges of filters were eliminated with a Po-210 radioactive source.

The quartz fibre filters were analysed using a thermaloptical carbon analyser (TOA; Sunset Laboratory Inc., Oregon). This analysis proceeded in two phases. In the first phase, the $\mathrm{OC}$ and carbonate carbon were volatilized in pure helium atmosphere at four temperature steps. During the second phase of the analysis, the carbon remaining on the filter
Table 1. Experimental parameters of the thermal-optical carbon analysis (TOA) method used in this study and those of two wellknown methods (NIOSH and IMPROVE).

\begin{tabular}{lccc}
\hline Carrier gas & This study & NIOSH $^{\mathrm{a}}$ & IMPROVE $^{\mathrm{a}}$ \\
\hline $\mathrm{He}-1(\mathrm{OC} 1)$ & $310^{\circ} \mathrm{C}, 60 \mathrm{~s}$ & $310^{\circ} \mathrm{C}, 60 \mathrm{~s}$ & $250^{\circ} \mathrm{C}, 150 \mathrm{~s}$ \\
$\mathrm{He}-2(\mathrm{OC} 2)$ & $480^{\circ} \mathrm{C}, 60 \mathrm{~s}$ & $475^{\circ} \mathrm{C}, 60 \mathrm{~s}$ & $450^{\circ} \mathrm{C}, 150 \mathrm{~s}$ \\
$\mathrm{He}-3(\mathrm{OC} 3)$ & $615^{\circ} \mathrm{C}, 60 \mathrm{~s}$ & $615^{\circ} \mathrm{C}, 60 \mathrm{~s}$ & $615^{\circ} \mathrm{C}, 250 \mathrm{~s}$ \\
$\mathrm{He}-4(\mathrm{OC} 4)$ & $900^{\circ} \mathrm{C}, 90 \mathrm{~s}$ & $870^{\circ} \mathrm{C}, 90 \mathrm{~s}$ & \\
$\mathrm{He} / \mathrm{O}_{2} \mathrm{~b}$ & $550^{\circ} \mathrm{C}, 60 \mathrm{~s}$ & $550^{\circ} \mathrm{C}, 45 \mathrm{~s}$ & $550^{\circ} \mathrm{C}, 200 \mathrm{~s}$ \\
$\mathrm{He} / \mathrm{O}_{2} \mathrm{~b}$ & $625^{\circ} \mathrm{C}, 60 \mathrm{~s}$ & $625^{\circ} \mathrm{C}, 45 \mathrm{~s}$ & \\
$\mathrm{He} / \mathrm{O}_{2} \mathrm{~b}$ & $700^{\circ} \mathrm{C}, 45 \mathrm{~s}$ & $700^{\circ} \mathrm{C}, 45 \mathrm{~s}$ & $700^{\circ} \mathrm{C}, 160 \mathrm{~s}$ \\
$\mathrm{He} / \mathrm{O}_{2} \mathrm{~b}$ & $775^{\circ} \mathrm{C}, 45 \mathrm{~s}$ & $775^{\circ} \mathrm{C}, 45 \mathrm{~s}$ & \\
$\mathrm{He} / \mathrm{O}_{2} \mathrm{~b}$ & $850^{\circ} \mathrm{C}, 45 \mathrm{~s}$ & $850^{\circ} \mathrm{C}, 45 \mathrm{~s}$ & $850^{\circ} \mathrm{C}, 200 \mathrm{~s}$ \\
$\mathrm{He} / \mathrm{O}_{2} \mathrm{~b}$ & $920^{\circ} \mathrm{C}, 60 \mathrm{~s}$ & $890^{\circ} \mathrm{C}, 120 \mathrm{~s}$ & \\
\hline
\end{tabular}

a Sciare et al. (2003)

${ }^{b}$ A mixture of $2 \%$ oxygen in helium.

was heated in a mixture of oxygen and helium $(1: 49, \mathrm{~V}-\%)$ by using six temperature steps. The temperature program used in this study followed the well-known NIOSH program with minor modifications (Table 1). A part of the OC pyrolysed into compounds resembling the EC during heating. An optical correction, i.e. a measurement of the transmittance of laser light through the filter, was applied for a separation of the pyrolysed OC from the EC that was determined as the fraction of carbon that comes out after the transmittance has reached its initial value. The POM is obtained by summing up the OC peaks and pyrolysed OC, and multiplying the sum by a factor of 1.4 (Turpin et al., 2000 and Russell, 2003). An analogous method has been described in detail by Viidanoja et al. (2002).

The carbonaceous material was divided into six thermal fractions labelled as follows: $\mathrm{OC} 1\left(310^{\circ} \mathrm{C}\right), \mathrm{OC} 2\left(480^{\circ} \mathrm{C}\right)$, OC3 $\left(615^{\circ} \mathrm{C}\right), \mathrm{OC}\left(900^{\circ} \mathrm{C}\right), \mathrm{OCP}$ (pyrolysed OC) and EC (sum of EC thermal fractions). $\mathrm{C}\left(\mathrm{CO}_{3}\right)$ refers to the carbonate carbon.

The PTFE filters were analysed by energy dispersive $\mathrm{X}$-ray fluorescence (ED-XRF) for their total $\mathrm{Ca}$ content; by ion chromatography (IC) for water-soluble $\mathrm{Ca}^{2+}$, succinate, malonate and oxalate; by liquid chromatography mass spectrometry (LC/MS) for monosaccharide anhydrides ( $\sum$ MA=levoglucosan+galactosan+mannosan) and by inductively coupled plasma mass spectrometry (ICP-MS) for As, $\mathrm{Cu}, \mathrm{Ni}, \mathrm{V}$ and $\mathrm{Zn}$. The techniques and their methodological uncertainties have been described elsewhere by Sillanpää et al. (2005).

The $\mathrm{CaCO}_{3}$ concentrations were converted from those of $\mathrm{CO}_{3}^{2-}$ and $\mathrm{Ca}$, analysed by the TOA and ED-XRF, respectively, using the following equations:

$\left[\mathrm{CaCO}_{3}\right]_{\mathrm{TOA}}=\frac{\mathrm{M}\left(\mathrm{CaCO}_{3}\right)}{\mathrm{M}\left(\mathrm{C}\left(\mathrm{CO}_{3}\right)\right)}\left[\mathrm{C}\left(\mathrm{CO}_{3}\right)\right]=8.334 \times\left[\mathrm{C}\left(\mathrm{CO}_{3}\right)\right](1)$ 


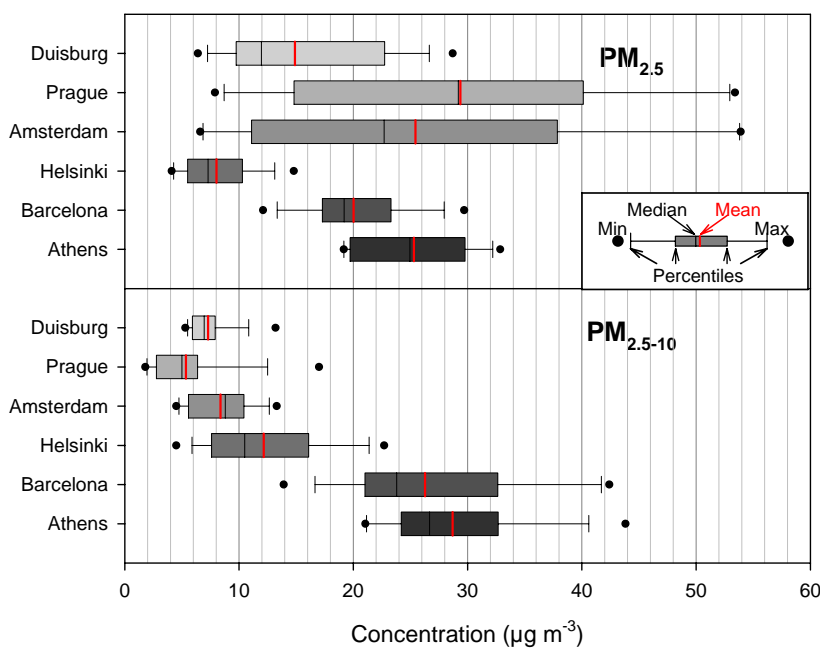

Fig. 1. The arithmetic mean, median and range as well as the 10th, 25th, 75th and 90th percentile values of the mass concentrations of fine $\left(\mathrm{PM}_{2.5}\right)$ and coarse $\left(\mathrm{PM}_{2.5-10}\right)$ particulate matter in the six sampling campaigns.

$\left[\mathrm{CaCO}_{3}\right]_{\mathrm{XRF}}=\frac{\mathrm{M}\left(\mathrm{CaCO}_{3}\right)}{\mathrm{M}(\mathrm{Ca})}[\mathrm{Ca}]=2.497 \times[\mathrm{Ca}]$,

where $\left[\mathrm{C}\left(\mathrm{CO}_{3}\right)\right]$ and $[\mathrm{Ca}]$ are the mass concentration of carbonate carbon and calcium. The area of the $\mathrm{C}\left(\mathrm{CO}_{3}\right)$ peak in TOA thermograms was manually integrated with the integral start at 210-225 s and end at 250-275 s. The $\mathrm{C}\left(\mathrm{CO}_{3}\right)$ peak was initially localised by comparing the analysis results of the original Athens sample to its duplicate that was decarbonated in $\mathrm{HCl}$ fumes as described by Cachier et al. (1989).

\subsection{Tracers for assessment of POM sources in $\mathrm{PM}_{2.5}$}

An assessment of five common sources of the fine particulate OC content was based on the mass concentration ratio of selected inorganic and organic tracers to POM. The $\mathrm{EC}$ is directly emitted from combustion of fossil fuels or/and biomass. It is often regarded as a tracer of local traffic (Song et al, 2001). Several studies have associated $\mathrm{Cu}$ and $\mathrm{Zn}$ emissions with traffic and metal industries (Pakkanen et al., 2001; Heal et al., 2005; Lim et al., 2005; Song et al., 2001). In the absence of a strong metal industry influence, As can be used as a tracer of coal combustion (NAEI, 2003), and Ni and V as tracers of fuel oil combustion (Song et al., 2001; Kavouras et al., 2001). The sum of three monosaccharide anhydrides ( $\sum \mathrm{MA}$; mainly levoglucosan) is known as a good tracer of incomplete biomass combustion (Simoneit et al., 1999; Sillanpää et al., 2005). The small dicarboxylic acids (DA; sum of oxalate, malonate and succinate) are mostly produced in photochemical reactions of anthropogenic organic pollutants in the urban atmosphere (Kawamura and Ikushima, 1993) but they can be also primary emissions from motor vehicle engines (Yao et al., 2004). Here the ratio of DA to POM was used as an indicator of secondary organic compounds.

\section{Results and discussion}

\section{1 $\mathrm{PM}_{2.5}$ and $\mathrm{PM}_{2.5-10}$ mass concentrations}

The mass concentrations of $\mathrm{PM}_{2.5}$ and $\mathrm{PM}_{2.5-10}$ during the 7 -week campaigns in the six European cities are shown in Fig. 1. The arithmetic mean concentrations were 14.7 and $7.2 \mu \mathrm{g} \mathrm{m}^{-3}$ in Duisburg, 29.6 and $5.4 \mu \mathrm{g} \mathrm{m}^{-3}$ in Prague, 25.4 and $8.4 \mu \mathrm{g} \mathrm{m}^{-3}$ in Amsterdam, 8.3 and $12.8 \mu \mathrm{g} \mathrm{m}^{-3}$ in Helsinki, 20.0 and $26.3 \mu \mathrm{g} \mathrm{m}^{-3}$ in Barcelona, and 25.3 and $28.7 \mu \mathrm{g} \mathrm{m}^{-3}$ in Athens, respectively. The highest mean $\mathrm{PM}_{2.5}$ concentration was measured in Prague during winter and the highest mean $\mathrm{PM}_{2.5-10}$ concentration was measured in Athens during summer, whereas the corresponding lowest values were in Helsinki during spring and in Prague during winter. For comparison (data from local authorities), the annual mean $\mathrm{PM}_{2.5}$ and $\mathrm{PM}_{2.5-10}$ mass concentrations in 2001 were, respectively, as follows: 23.0 and $6.8 \mu \mathrm{g} \mathrm{m}^{-3}$ in Duisburg, 7.8 and $7.9 \mu \mathrm{g} \mathrm{m}^{-3}$ in Helsinki, and 28.0 and $13.0 \mu \mathrm{g} \mathrm{m}^{-3}$ in Barcelona. These two size fractions were not measured in the other three cities but the annual mean $\mathrm{PM}_{10}$ mass concentrations in 2001 were $24.5 \mu \mathrm{g} \mathrm{m}^{-3}$ in Prague, $28.9 \mu \mathrm{g} \mathrm{m}^{-3}$ in Amsterdam and $55.5 \mu \mathrm{g} \mathrm{m}^{-3}$ in Athens. Our sampling campaign means were clearly higher than the corresponding annual means for Prague$\mathrm{PM}_{10}$ (43\%), Amsterdam-PM 10 (17\%), Helsinki-PM $2.5-10$ $(62 \%)$ and Barcelona-PM $\mathrm{PM}_{2.5}-10(100 \%)$, suggesting special source-related, episodic or seasonal impacts during the campaigns in these cities. Marginal difference with the historical annual mean value was found for Duisburg- $\mathrm{PM}_{2.5-10}(5.9 \%)$, Helsinki-PM $2.5(6.4 \%)$ and Athens-PM $\mathrm{PM}_{10}(-2.7 \%)$, but our campaign means were clearly lower than the annual means of 2001 for Duisburg- $\mathrm{PM}_{2.5}(-36 \%)$ and Barcelona- $\mathrm{PM}_{2.5}$ $(-29 \%)$.

The mean $\mathrm{PM}_{2.5-10}$ to $\mathrm{PM}_{2.5}$ ratios were clearly lower in Duisburg (0.58), Prague (0.20) and Amsterdam (0.54) than in Helsinki (1.57), Barcelona (1.36) and Athens (1.14). The differences were most likely due to factors related to the season, local emission sources and geographical location. The first three sampling campaigns were carried out during the 'wet' and cool seasons favouring a low $\mathrm{PM}_{2.5-10}$ concentration (due to low resuspension) and a high $\mathrm{PM}_{2.5}$ concentration (additional local and regional energy production for heating). The sampling campaigns in Barcelona and Athens were conducted during warmer and drier seasons leading to a lower $\mathrm{PM}_{2.5}$ concentration (semivolatiles in gas phase) and a high $\mathrm{PM}_{2.5-10}$ concentration (resuspension). Road dust episodes, typical phenomena of springtime in Northern Europe, were the reason for elevated $\mathrm{PM}_{2.5-10}$ in Helsinki (Kukkonen et al., 1999). More detailed data on the particulate mass concentrations, meteorology and air quality during the sampling campaigns will be reported elsewhere. 


\subsection{Mass concentrations of EC and POM in six cities}

The POM and EC mass concentrations in $\mathrm{PM}_{2.5}$ and $\mathrm{PM}_{2.5-10}$ of the six sampling campaigns are shown in Fig. 2. The arithmetic mean POM concentrations in $\mathrm{PM}_{2.5}$ varied profoundly between $3.8 \mu \mathrm{g} \mathrm{m}^{-3}$ in Helsinki and $15.7 \mu \mathrm{g} \mathrm{m}^{-3}$ in Prague, while the corresponding EC concentrations varied much less, i.e. between $0.68 \mu \mathrm{g} \mathrm{m}^{-3}$ in Helsinki and $1.6 \mu \mathrm{g} \mathrm{m}^{-3}$ in Athens. The mean POM (corrected for $\mathrm{C}\left(\mathrm{CO}_{3}\right)$, see Sect. 3.3.1) and EC mass concentrations in $\mathrm{PM}_{2.5-10}$ varied in the range of $1.2-5.0 \mu \mathrm{g} \mathrm{m}^{-3}$ and $0.18-$ $0.28 \mu \mathrm{g} \mathrm{m}^{-3}$, respectively. The lowest mean POM and EC in $\mathrm{PM}_{2.5-10}$ were observed in Amsterdam, while the corresponding highest concentrations were in Athens. The mean OC concentrations in $\mathrm{PM}_{2.5}$ and $\mathrm{PM}_{2.5-10}$ of the backup filters varied in the range of $0.32-1.31$ and $0.12-0.33 \mu \mathrm{g} \mathrm{m}^{-3}$, corresponding to $5.7-19 \%$ and $5.8-14 \%$ of the OC on the front filters, respectively. The EC contributions were about one tenth of those of the $\mathrm{OC}$, which was also anticipated because of the nonvolatile nature of elemental carbon.

In this study, the POM in both the $\mathrm{PM}_{2.5}$ and $\mathrm{PM}_{2.5-10}$ was obtained with multiplication of the OC concentration by a factor of 1.4 in each city. This adjustment was made to include a contribution of other elements than the carbonaceous material (OC) of organic compounds to POM (Turpin et al., 2000 and Russell, 2003). The use of this conversion factor should be regarded as a rough means to compensate the limitations of present analytical instruments (e.g. FTIR spectroscopy or GC/MS).

Querol et al. (2004) has reported in their European multicentre study that the annual mean mass concentration of total carbon (TC; sum of $\mathrm{OC}$ and $\mathrm{EC}$ ) in $\mathrm{PM}_{2.5}$ varied in the range of $2-8 \mu \mathrm{g} \mathrm{m}^{-3}$ at urban background sites. Our campaignmean TC concentrations in $\mathrm{PM}_{2.5}$ fell into this range in all other campaigns than Prague $\left(12.6 \mu \mathrm{g} \mathrm{m}^{-3}\right)$. In the study of Querol et al. (2004), the annual mean TC mass concentrations in $\mathrm{PM}_{2.5-10}$ were in the range of $0-1 \mu \mathrm{g} \mathrm{m}^{-3}$. Our campaign-mean TCs were between 1.0 and $1.9 \mu \mathrm{g} \mathrm{m}^{-3}$, except for the high value of $3.9 \mu \mathrm{g} \mathrm{m}^{-3}$ in Athens.

The relative contributions of carbonaceous material to $\mathrm{PM}_{2.5}$ and $\mathrm{PM}_{2.5-10}$ are shown in Table 2. The POM contributions to $\mathrm{PM}_{2.5}$ were very high, ranging from $21 \%$ in Barcelona to $54 \%$ in Prague, while those to $\mathrm{PM}_{2.5-10}$ were generally lower, i.e. from $10 \%$ in Barcelona to $27 \%$ in Prague. As expected, the EC contributions to $\mathrm{PM}_{2.5}$ (5-9\%) were higher than those to $\mathrm{PM}_{2.5-10}(1-6 \%)$ in all the six campaigns. Putaud et al. (2004) have made a meta-analysis of the annual mean black carbon (BC) and POM contributions based on measurements at urban background sites of eight European cities. The mean $\mathrm{BC}$ contributions to $\mathrm{PM}_{2.5}$ and $\mathrm{PM}_{2.5-10}$ were $8 \%$ and $3 \%$, respectively, which agrees well with our present results. In contrast, their annual mean POM contributions to $\mathrm{PM}_{2.5}$ and $\mathrm{PM}_{2.5-10}$ were only $22 \%$ and $8 \%$, i.e. values similar to our smallest campaign-means and about one-third to one-half of our largest campaign-means. De-

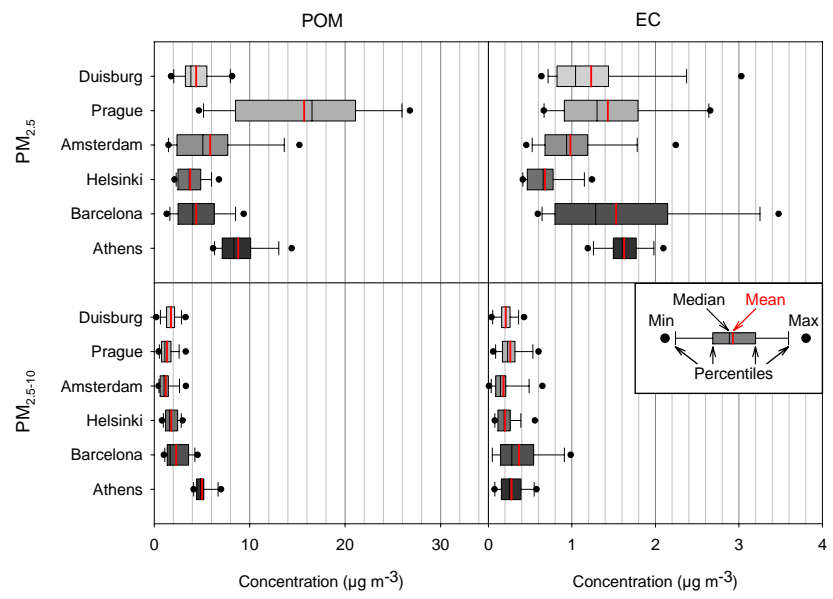

Fig. 2. The arithmetic mean, median and range as well as the 10th, 25th, 75th and 90th percentile values of the particulate organic matter (POM) and elemental carbon (EC) concentrations in $\mathrm{PM}_{2.5}$ and $\mathrm{PM}_{2.5-10}$ of the six sampling campaigns.

spite the differences in sample collection and analysis techniques between our study and the other European studies, this finding suggests that the selected campaign periods of public health concern in several cities (e.g., Prague, Athens, Helsinki) were associated with a relatively high POM content.

It is worthwhile noting that the EC and OC results are dependent on the method used in the thermal-optical carbon analysis. Chow et al. (2001) have shown that the NIOSH and IMPROVE methods (Table 1) are equivalent for total carbon but the EC of NIOSH (usually a smaller fraction of TC) is typically less than half of the value of the EC of IMPROVE. A reasonable estimate for the EC probably lies somewhere between the values given by these two methods (Sciare et al., 2003). We used a slightly modified NIOSH method (see Table 1) and, therefore, the EC concentrations may be somewhat underestimated and the OC concentrations slightly overestimated in the present study.

The mean $\mathrm{PM}_{2.5-10}$ to $\mathrm{PM}_{2.5}$ ratio of the $\mathrm{EC}$ ranged between 0.17 and 0.29 . These low ratios indicate that the EC existed mainly in $\mathrm{PM}_{2.5}$, which has been observed in many European urban environments (Viidanoja et al., 2002; Salma et al., 2004). The mean $\mathrm{PM}_{2.5-10}$ to $\mathrm{PM}_{2.5}$ ratio of $\mathrm{POM}$ had a much larger range than that of the EC, being 0.094 for Prague, 0.24 for Amsterdam, 0.45 for Duisburg, 0.50 for Helsinki, 0.56 for Barcelona and 0.59 for Athens. The ratios were lower for sampling campaigns with a lower mean ambient temperature and a higher precipitation (see Sect. 2.1).

\subsection{Assessment of POM and EC sources in $\mathrm{PM}_{2.5}$}

The Pearson correlation coefficients between the total mass concentration, $\mathrm{POM}$ and $\mathrm{EC}$ in $\mathrm{PM}_{2.5}$ and $\mathrm{PM}_{2.5-10}$ are shown in Table 3 . The fine POM concentration had a high 
Table 2. The relative contribution (\%) of particulate organic matter (POM) and elemental carbon (EC) to the total mass (PM) in $\mathrm{PM} 2.5$ and $\mathrm{PM}_{2.5-10}$ as well as the ratio of organic carbon (OC) to EC in the six sampling campaigns.

\begin{tabular}{|c|c|c|c|c|c|c|c|c|c|c|c|}
\hline & & \multicolumn{3}{|c|}{$\mathrm{POM} / \mathrm{PM}(\%)$} & \multicolumn{3}{|c|}{$\mathrm{EC} / \mathrm{PM}(\%)$} & \multicolumn{3}{|c|}{ OC/EC } & \multirow{2}{*}{$\begin{array}{c}\mathrm{BU} / \mathrm{F}-\mathrm{OC}{ }^{\mathrm{a}}(\%) \\
\mathrm{Mean} \pm \mathrm{SD}\end{array}$} \\
\hline & & Mean (SD) & Min & Max & Mean (SD) & Min & Max & Mean (SD) & Min & Max & \\
\hline \multirow[t]{6}{*}{$\mathrm{PM}_{2.5}$} & Duisburg & $31(6)$ & 21 & 38 & $9.0(3.1)$ & 4.7 & 15 & $2.7(0.9)$ & 1.7 & 5.2 & $16 \pm 7$ \\
\hline & Prague & $54(4)$ & 48 & 60 & $5.7(2.7)$ & 1.3 & 11 & $8.7(6.0)$ & 3.6 & 27 & $6 \pm 2$ \\
\hline & Amsterdam & $23(4)$ & 19 & 29 & $5.4(3.4)$ & 1.7 & 13 & $4.3(2.6)$ & 1.2 & 9.8 & $12 \pm 5$ \\
\hline & Helsinki & $46(6)$ & 34 & 57 & $8.4(1.8)$ & 4.5 & 11 & $4.0(0.9)$ & 2.8 & 6.3 & $14 \pm 3$ \\
\hline & Barcelona & $21(11)$ & 8.9 & 49 & $7.6(4.5)$ & 3.1 & 18 & $2.1(0.5)$ & 1.5 & 3.1 & $17 \pm 3$ \\
\hline & Athens & $35(4)$ & 30 & 47 & $6.8(1.4)$ & 4.9 & 9.4 & $3.9(0.9)$ & 2.7 & 5.4 & $19 \pm 3$ \\
\hline \multirow{6}{*}{$\mathrm{PM}_{2.5-10}$} & Duisburg & $24(8)$ & 3.4 & 37 & $2.9(1.2)$ & 0.48 & 5.0 & $9.1(9.8))$ & 0.7 & 39 & $14 \pm 19$ \\
\hline & Prague & $27(7)$ & 16 & 41 & $5.5(2.6)$ & 2.2 & 11 & $3.9(1.5)$ & 2.0 & 7.3 & $10 \pm 5$ \\
\hline & Amsterdam & $15(8)$ & 5.6 & 28 & $2.3(1.5)$ & 0.06 & 5.4 & $11(21)$ & 3.4 & 84 & $12 \pm 3$ \\
\hline & Helsinki & $15(4)$ & 11 & 25 & $1.6(0.6)$ & 0.84 & 2.7 & $7.1(2.3)$ & 3.8 & 13.6 & $8 \pm 3$ \\
\hline & Barcelona & $10(6)$ & 2.7 & 23 & $1.1(0.9)$ & 0.15 & 3.2 & $9.0(5.5)$ & 4.1 & 18.1 & $9 \pm 4$ \\
\hline & Athens & $24(3)$ & 19 & 30 & $1.0(0.4)$ & 0.23 & 1.9 & 24 (17) & 9.5 & 62 & $6 \pm 1$ \\
\hline
\end{tabular}

${ }^{a} \mathrm{BU} / \mathrm{F}-\mathrm{OC}$ is the ratio of OC on backup filter to OC on front filter.

Table 3. The Pearson correlation coefficients (r) between the total particulate mass, POM, and EC in $\mathrm{PM}_{2.5}$ and $\mathrm{PM}_{2.5-10}$.

\begin{tabular}{lcccccc}
\hline & Duisburg & Prague & Amsterdam & Helsinki & Barcelona & Athens \\
\hline $\mathrm{PM}_{2.5}$ vs. $\mathrm{PM}_{2.5-10}$ & 0.280 & 0.554 & -0.128 & 0.584 & 0.295 & 0.717 \\
$\mathrm{EC}_{2.5}$ vs. $\mathrm{EC}_{2.5-10}$ & 0.524 & 0.379 & $\mathbf{0 . 8 7 5}$ & $\mathbf{0 . 8 1 0}$ & $\mathbf{0 . 8 8 4}$ & 0.348 \\
$\mathrm{POM}_{2.5}$ vs. $\mathrm{POM}_{2.5-10}$ & 0.542 & 0.661 & $\mathbf{0 . 8 9 7}$ & 0.498 & $\mathbf{0 . 8 2 4}$ & $\mathbf{0 . 8 0 0}$ \\
$\mathrm{PM}_{2.5}$ vs. $\mathrm{EC}_{2.5}$ & 0.553 & 0.360 & 0.664 & 0.722 & 0.341 & 0.405 \\
$\mathrm{PM}_{2.5}$ vs. $\mathrm{POM}_{2.5}$ & $\mathbf{0 . 8 4 4}$ & $\mathbf{0 . 9 8 7}$ & $\mathbf{0 . 9 5 9}$ & $\mathbf{0 . 8 9 7}$ & 0.567 & $\mathbf{0 . 8 6 0}$ \\
$\mathrm{EC}_{2.5}$ vs. $\mathrm{POM}_{2.5}$ & 0.672 & 0.436 & 0.762 & 0.790 & $\mathbf{0 . 9 4 5}$ & 0.517 \\
$\mathrm{PM}_{2.5-10}$ vs. $\mathrm{EC}_{2.5-10}$ & 0.352 & $\mathbf{0 . 8 2 2}$ & 0.208 & 0.696 & -0.087 & 0.470 \\
$\mathrm{PM}_{2.5}$-10 vs. $\mathrm{POM}_{2.5-10}$ & 0.651 & $\mathbf{0 . 9 3 5}$ & 0.263 & $\mathbf{0 . 9 0 4}$ & -0.073 & $\mathbf{0 . 8 3 1}$ \\
$\mathrm{EC}_{2.5-10}$ vs. $\mathrm{POM}_{2.5-10}$ & 0.198 & $\mathbf{0 . 8 2 8}$ & $\mathbf{0 . 9 2 6}$ & $\mathbf{0 . 8 1 3}$ & $\mathbf{0 . 8 7 0}$ & 0.659 \\
\hline
\end{tabular}

High correlations $(r \geq 0.80)$ bolded.

correlation ( $r=0.84-0.99)$ with the $\mathrm{PM}_{2.5}$ concentration in all cities except for Barcelona $(r=0.57)$ where the POM had the smallest contribution to $\mathrm{PM}_{2.5}$. However, the POM and EC in $\mathrm{PM}_{2.5}$ of Barcelona were highly intercorrelated $(r=0.95)$, which together with the lowest OC to EC ratio (see next paragraph) suggests that they had a common dominant source different from the other cities, e.g. fuel oil combustion in numerous ship engines at the large harbour. The fine EC concentration had a relatively low correlation $(r=0.34-0.72)$ with the $\mathrm{PM}_{2.5}$ concentration in all the six campaigns, but it correlated highly $(r=0.81-0.88)$ with the coarse EC in Amsterdam, Helsinki and Barcelona, suggesting impacts from local combustion sources not only to $\mathrm{PM}_{2.5}$ but also to $\mathrm{PM}_{2.5-10}$. Only in the winter campaign of Prague, the coarse EC concentration had a high correlation $(r=0.82)$ with the $\mathrm{PM}_{2.5-10}$ concentration, which refers to local incomplete combustion processes such as residential heating with solid fuels. The coarse POM concentration correlated highly $(r=0.83-0.94)$ with the $\mathrm{PM}_{2.5-10}$ concentration in Prague, Helsinki and Athens, which reflects its highly variable anthropogenic and natural sources in different urban environments and seasons (Table 3).

The OC to EC ratios in $\mathrm{PM}_{2.5}$ were in the range of 2.14.3 in Barcelona, Duisburg, Athens, Helsinki and Amsterdam, but it was much higher (8.7) in Prague (Table 2). Na et al. (2004) have reviewed some of the reported OC to EC ratios in relation to a variety of combustion sources. A low OC to EC ratio has been associated with traffic sources $(2.2$ and 0.8 for light-duty gasoline and heavy-duty diesel vehicles, respectively), whereas residential heating (wood combustion 4.15 and natural gas home appliance 12.7), forest fire (14.5) and dust from paved roads (13.1) have shown remarkably higher ratios. 
Figure 3 shows the mass concentration ratios in $\mathrm{PM}_{2.5}$ of the selected inorganic and organic tracers (see Sect. 2.4.) of five common sources of organic material to POM.

Traffic. Road traffic has certainly a substantial impact on the POM concentration in $\mathrm{PM}_{2.5}$ of all the six urban background sites. As assessed from the ratio of $\mathrm{EC}, \mathrm{Cu}$ and $\mathrm{Zn}$ to POM, its relative impact was largest in Barcelona and Duisburg, and smallest in Prague (Fig. 3). However, the high ratios of $\mathrm{Cu}$ and $\mathrm{Zn}$ to POM in Duisburg were likely to be at least partially due to emissions from the large metal industries in the Ruhr area.

Coal combustion. According to the As to POM ratio in $\mathrm{PM}_{2.5}$, the contribution of coal combustion emissions was higher in Prague, Duisburg, Amsterdam and Barcelona than in Helsinki and Athens (Fig. 3). The first three cities had sampling campaigns during the cold and wet seasons, which means that their findings can be explained by increased local and regional residential heating, and larger-scale energy production, with coal. In Barcelona, the impact may be derived from the emissions from coal plants located nearby the city (Rodríguez et al., 2002).

Fuel oil combustion. As assessed from the ratios of $\mathrm{Ni}$ and $\mathrm{V}$ to POM, the contribution of fuel oil combustion was clearly highest in Barcelona followed by Helsinki, Amsterdam and Athens (Fig. 3). Ships in the harbours of these cities can be regarded as the major source, because it seemed to have a low impact in the inland cities of Duisburg and Prague. The large metal industries in the Ruhr area probably elevated the Ni contribution to $\mathrm{PM}_{2.5}$ of Duisburg to some extent, but the $\mathrm{V}$ contribution remained low. The ratio of $\mathrm{Ni}$ to $\mathrm{V}$ in $\mathrm{PM}_{2.5}$ is expected to be around 0.38 in relation to impact from fuel oil combustion (Kavouras et al., 2001), which was close in all other cities (0.27-0.45) than Duisburg (0.57) (Fig. 3).

Biomass combustion. According to the $\sum \mathrm{MA}$ to POM ratio, the contribution of biomass combustion was clearly higher in Prague, Amsterdam and Duisburg than in Helsinki, Barcelona and Athens (Fig. 3). The differences can be explained by an impact from local or regional residential heating, since the three former campaigns were carried out during the cold and wet seasons. In Prague, the very high mass concentration of POM in $\mathrm{PM}_{2.5}$ (Fig. 2) as well as the above described high correlations of both the coarse EC and POM with the $\mathrm{PM}_{2.5-10}$ concentration (Table 3) suggest a larger contribution from local biomass combustion than in Amsterdam and Duisburg.

Secondary POM. The DA to POM ratios in the springtime and summertime campaigns of Helsinki, Barcelona and Athens were 2-9 times higher than those in the autumn and winter campaigns of Duisburg, Prague and Amsterdam (Fig. 3). The likely reason for this difference is enhanced photochemical oxidation of organic compounds in the spring and summer (Kamamura and Ikushima, 1993).

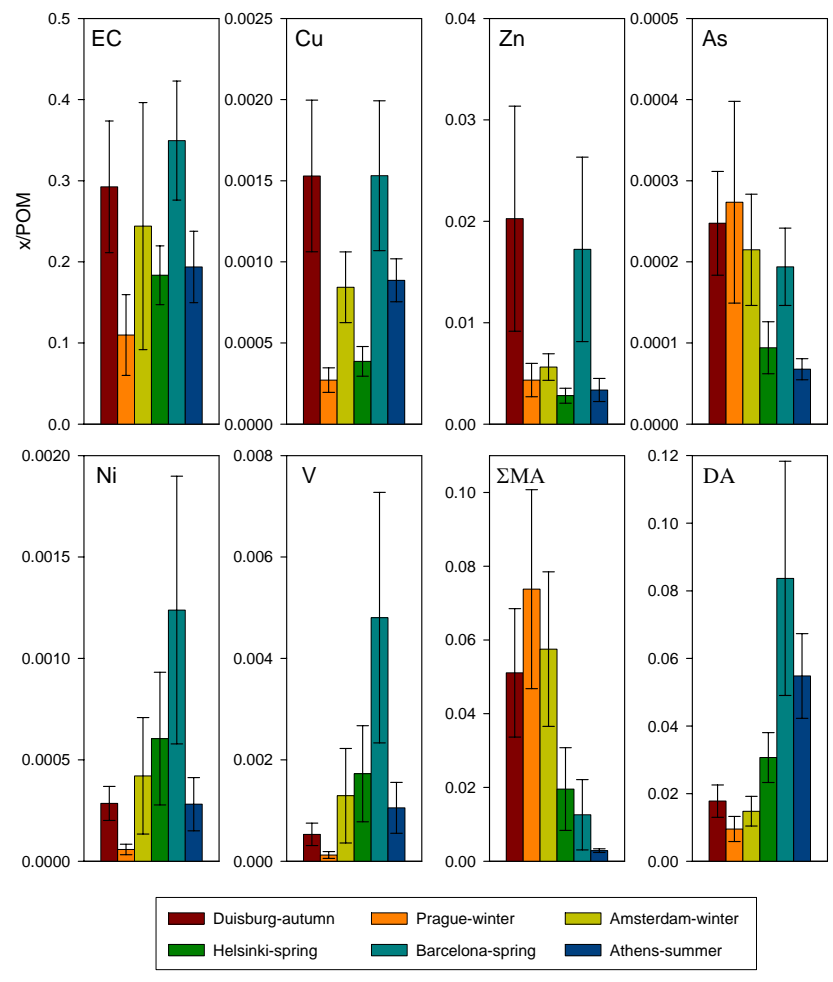

Fig. 3. The mass concentration ratios of the selected tracers of common emission sources of organic material to POM in $\mathrm{PM}_{2.5}$. The values are means \pm SD of 14 samples collected during a 7-week sampling campaign in each city. See text for further explanation.

\subsection{Analysis of thermal fractions}

\subsubsection{Carbonate in atmospheric particles}

The carbonate-carbon $\left(\mathrm{C}\left(\mathrm{CO}_{3}\right)\right)$ can interfere with the TOA analysis during the OC4 step (Fig. 4) and cause a positive artefact to the OC concentration (Sciare et al., 2003). In this study, $\mathrm{C}\left(\mathrm{CO}_{3}\right)$ could be quantified in the $\mathrm{PM}_{2.5-10}$ samples of Barcelona and Athens, but it was not detected either in the $\mathrm{PM}_{2.5-10}$ samples of the other four cities or in the $\mathrm{PM}_{2.5}$ samples of any city. The mean $\mathrm{C}\left(\mathrm{CO}_{3}\right)$ to $\mathrm{OC}$ ratio in $\mathrm{PM}_{2.5-10}$ was 0.17 in Barcelona and 0.53 in Athens, which indicates that the OC (and subsequently POM) concentration in certain situations can be grossly overestimated without a subtraction of the $\mathrm{C}\left(\mathrm{CO}_{3}\right)$. We subtracted the $\mathrm{C}\left(\mathrm{CO}_{3}\right)$ concentration from the $\mathrm{OC} 4$ and total $\mathrm{OC}$ concentration before conversion of the OC results to POM shown in Sect. 3.2.

A time-series of the $\mathrm{CaCO}_{3}$ concentration in the $\mathrm{PM}_{2.5-10}$ samples from Athens and Barcelona is shown in Fig. 5. The campaign mean (range), based on Eq. (1), was 15.9 (9.829.2) $\mu \mathrm{g} \mathrm{m}^{-3}$ for Athens, whereas the corresponding value for Barcelona was $2.6(0.3-6.3) \mu \mathrm{g} \mathrm{m}^{-3}$. These concentrations accounted for $55( \pm 8) \%$ and $11( \pm 9) \%$ of the $\mathrm{PM}_{2.5-10}$ concentration in Athens and Barcelona, respectively. There was a high linear correlation $(r=0.91)$ and the slope close 


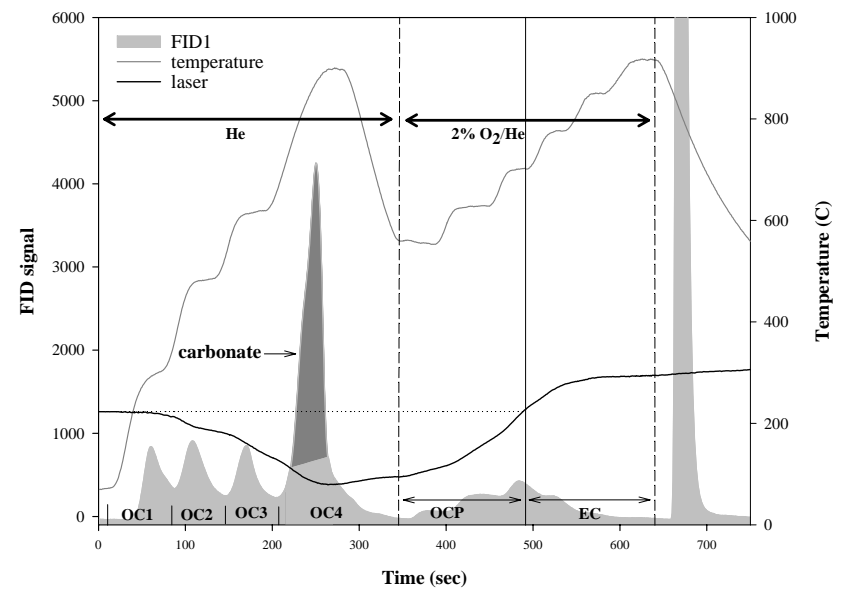

Fig. 4. Example of the temperature program in the thermal-optical carbon analysis (TOA) and a manually integrated carbonate $\mathrm{C}\left(\mathrm{CO}_{3}\right)$ peak in the present study ( $\mathrm{PM}_{2.5-10}$ sample \#14 from Athens). See text and Table 1 for other explanations.

to unity between the $\left[\mathrm{CaCO}_{3}\right]_{\mathrm{TOA}}$ and $\left[\mathrm{CaCO}_{3}\right]_{\mathrm{XRF}}$ concentrations (based on Eqs. (1) and (2)) in Athens, and a significant trend in Barcelona (Pearson's $r=0.61$ ) although the molar equivalent concentration of $\mathrm{CO}_{3}^{2-}$ was lower than that of $\mathrm{Ca}$ (Fig. 5). This indicates that the coarse $\mathrm{Ca}$ appeared exclusively as $\mathrm{CaCO}_{3}$ in Athens, whereas the coarse $\mathrm{Ca}$ in Barcelona existed partly in other forms (e.g. as oxide). A similar conclusion has been drawn by Bardouki et al. (2003) who discovered in ion balance calculation that the coarse $\mathrm{Ca}$ was strongly associated with $\mathrm{C}\left(\mathrm{CO}_{3}\right)$ (a molar ratio close to 1) during summertime in the Eastern Mediterranean.

Figure 6 shows the portion of crustal elements in the soil-derived coarse particles of the six sampling campaigns. These data further support the view of $\mathrm{CaCO}_{3}$ appearance in the $\mathrm{PM}_{2.5-10}$ samples of Athens and Barcelona. Calcium had its largest contributions to the $\mathrm{PM}_{2.5-10}$ of Athens and Barcelona, whereas $\mathrm{Al}$ and Si had major contributions in the other four cities. In addition, the fine-to-coarse ratio of total Ca was lower in Barcelona (0.064) and Athens (0.068) than in the other four cities $(0.086-0.183)$, indicating a strong coarse particle dominance in Ca distribution. The contribution of watersoluble $\mathrm{Ca}^{2+}$ to the total amount of $\mathrm{Ca}$ was determined on the basis of results from the IC (soluble fraction) and ED-XRF (total amount) analyses. A relatively low contribution of total $\mathrm{Ca}$ to $\mathrm{PM}_{2.5-10}$, together with its high water-solubility, in Duisburg, Prague and Amsterdam indicates that Calcium appeared mainly as water-soluble salts (e.g. oxide or sulphate) and not as poorly water-soluble salts like $\mathrm{CaCO}_{3}$. On the contrary, a high contribution of insoluble $\mathrm{Ca}$, together with a low $\mathrm{Si}$ contribution, to $\mathrm{PM}_{2.5-10}$ agrees well with the appearance of $\mathrm{CaCO}_{3}$ in Athens and Barcelona. In Helsinki, the relatively high insoluble $\mathrm{Ca}$ (about $50 \%$ of total), together with a high Si contribution, to $\mathrm{PM}_{2.5-10}$ suggests an appearance of other water-insoluble compounds such as Calcium silicates in the absence of $\mathrm{C}\left(\mathrm{CO}_{3}\right)$ (Fig. 6).

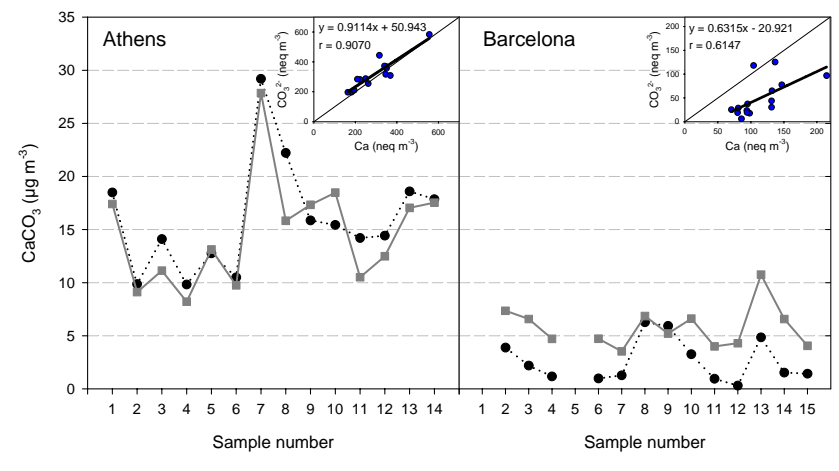

Fig. 5. Time-series of the mass concentration of $\mathrm{CaCO}_{3}$ in $\mathrm{PM}_{2.5-10}$ of Athens and Barcelona. The black dotted line is based on the $\mathrm{CO}_{3}^{2-}$ content analysed by the TOA, and the grey continuous line is based on the Ca content analysed by the ED-XRF. The linear regressions for the molar equivalent concentrations of $\mathrm{Ca}(\mathrm{x}-$ axis) and $\mathrm{CO}_{3}^{2-}$ (y-axis) are shown in the right upper corners of the panels for the two campaigns.

\subsubsection{Thermal fractions of $\mathrm{OC}$ in $\mathrm{PM}_{2.5}$}

The thermograms, i.e. the output from the TOA analysis of the OC and EC in the six-city samples, are comparable with each other, because the sampling devices, protocols and the analytical method were identical. The mean mass portions of the five OC thermal fractions in $\mathrm{PM}_{2.5}$ - labelled OC1, OC2, OC3, OC4 and OCP - varied in the range of $26-33 \%, 6-10 \%$, $7-10 \%, 9-22 \%$ and $29-50 \%$, respectively (Fig. 7). The differences in the mass portions were relatively small between the cities. However, there was a trend that the pyrolysed OC fraction was higher (OCP 50\%) in Prague than in the other cities (29-41\%) and, vice versa, the OC peaks at temperature steps of 480,615 and $900^{\circ} \mathrm{C}$ (i.e. OC2-OC4) were somewhat smaller in Prague than in the other cities.

The OC concentration in $\mathrm{PM}_{2.5}$ correlated inversely with the OC1 $(r=-0.32$ to -0.75$)$, OC2 $(r=-0.022$ to -0.58$)$, OC3 $(r=-0.51$ to -0.69$)$ and OC4 $(r=-0.31$ to -0.94$)$ in all the six-city data, whereas the OCP had a relatively high positive correlation with the OC ( $r=0.70$ to 0.93 ). This pattern in results suggests a too short residence time at each temperature step of the TOA method, which may be partly a consequence of the 3- to 4-day sampling duration and relatively large masses of $\mathrm{PM}_{2.5}$ particles on our filters. In any case, the too short residence time at temperature steps increases charring of the OC (Yu et al., 2002), irrespectively of the organic composition of particulate samples. The transmittance of laser light through the filter gradually decreases, which suggests that a part of $\mathrm{OC}$ is pyrolysed during each OC temperature step (OC1-OC4).

The dominating thermal fraction from the $\mathrm{PM}_{2.5}$ backup filters was OC1 (56-62\%), whereas the OC2-OC4 (10-16\%) and OCP $(0-3 \%)$ were found only in minor quantities. The thermogram profiles from the six-city samples were similar 


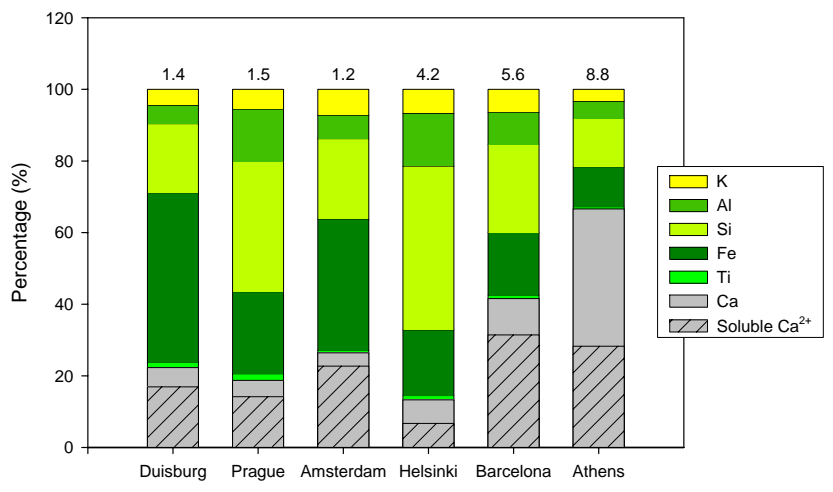

Fig. 6. The relative contribution (\%) of crustal elements (Ca, Ti, Fe, $\mathrm{Si}, \mathrm{Al}$ and $\mathrm{K}$ ) to the soil particles in $\mathrm{PM}_{2.5-10}$. The value above the bar indicates to the sum of mean concentrations $\left(\mu \mathrm{g} \mathrm{m}^{-3}\right)$ of the crustal elements during the six sampling campaigns. The portion of water-soluble $\mathrm{Ca}^{2+}$ from the total $\mathrm{Ca}$ is shown as a striped bar.

to each other, irrespective of the geographical location or season. In this study, the OC on the backup filter was anticipated to be comprised of adsorbed organic gases, but some part of it may have been formed via evaporation of semivolatile organics from particles collected on the front filter (Turpin et al., 2000). Regardless of its origin (positive or negative artefact), the OC on backup filter seemed to be easily volatile (i.e. a large $\mathrm{OC} 1$ ).

Only very limited conclusions can be drawn from the chemical content of thermal fractions, because the evolution of organic components depends on several factors. First, the presence of some catalytically active inorganic salts such as $\mathrm{Na}^{+}$and $\mathrm{K}^{+}$(Novakov and Corrigan, 1996) or ammonium sulphate and phosphate (Yu et al., 2002) can increase the combustion rate of certain compounds (Novakov and Corrigan, 1996) or the charring of insoluble organic materials (Yu et al., 2002). Second, as mentioned above, the too short steps of the temperature program cause overlapping of the OC peaks and increase the charring. Third, organic gases can be adsorbed on quartz filter with more than a single binding energy (Kirchstetter et al., 2001), which results in an appearance of a certain compound in more than one thermal fraction.

\section{Conclusions and implications}

The advantages of this study were as follows: 1) all the samples were collected using the same sampling devices and following a uniform protocol, 2) the samples were analysed with the same TOA method in one central laboratory, and 3 ) the long sampling duration and the use of filters from one manufacturing lot improved the accuracy of the tandem quartz filter subtraction method. All of these factors improved the comparability of the EC, OC and POM results between the six contrasting sampling campaigns. However, we

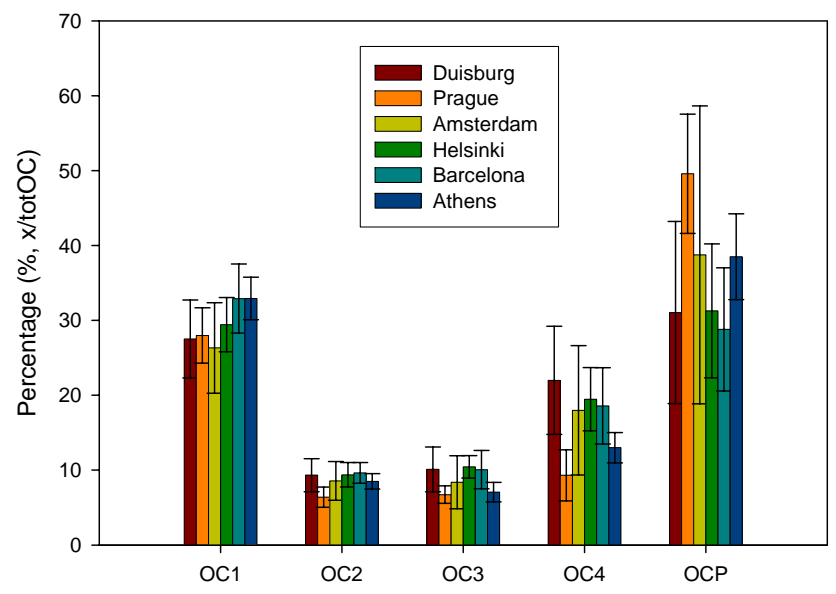

Fig. 7. The mean \pm SD relative contributions (\%) of the four OC thermal fractions (OC1-OC4) and pyrolysed OC (OCP) to the total $\mathrm{OC}$ in $\mathrm{PM}_{2.5}$ of the six sampling campaigns.

could not reliably separate the four thermal fractions (OC1OC4) and the pyrolysed OC from each other, because the residence time in our modified NIOSH programme of TOA was too short for the rather large amounts of particles on our filters. Moreover, the long sampling duration may have increased evaporative $\mathrm{OC}$ losses from collected particles.

Our present validation indicates that carbonate $\left(\mathrm{C}_{\left.\left(\mathrm{CO}_{3}\right)\right)}\right.$ in $\mathrm{PM}_{2.5-10}$ can be reliably quantified from the TOA thermograms and subtracted from the OC with the help of the described integration. This simple method can be used as an alternative for the more time-consuming $\mathrm{HCl}$ pre-treatment method (Cachier et al., 1989). In a future study, it would be worth while investigating, how $\mathrm{C}\left(\mathrm{CO}_{3}\right)$ behaves in the IMPROVE thermal program. As $\mathrm{CaCO}_{3}$ decomposes at a relatively high temperature of about $800^{\circ} \mathrm{C}$, its appearance in particulate samples would probably lead to an overestimation of the EC concentration compared to the NIOSH programme.

It is obvious that combustion emissions from vehicle engines affected the POM content in $\mathrm{PM}_{2.5}$ of all the six sampling campaigns. However, our analysis of the sources of organic material in POM revealed some important differences. The $\mathrm{PM}_{2.5}$ of Prague (winter) had obviously large impacts on POM from local residential heating with solid fuels (biomass, coal), while the POM in $\mathrm{PM}_{2.5}$ of Amsterdam (winter) and Duisburg (autumn) might be mainly impacted by regional aerosols from the same origins. The POM in $\mathrm{PM}_{2.5}$ of Barcelona (spring) seemed to have the largest relative contribution of all the six campaigns from fuel oil combustion, most likely in ships at the large harbour. Finally, the POM in $\mathrm{PM}_{2.5}$ of Barcelona (spring) and Athens (summer) seemed to have a much larger contribution than the other campaigns from secondary organic compounds formed in photochemical oxidative reactions in the atmosphere. The on-going toxicological studies will clarify the health significance of these findings. 
Acknowledgements. This study was conducted within the framework of the project "Chemical and biological characterisation of ambient air coarse, fine, and ultrafine particles for human health risk assessment in Europe" (PAMCHAR) co-ordinated by the National Public Health Institute of Finland (http://www.pamchar.org/). The project has been funded by the EC-FP5 Quality of Life and Management of Living Resources Programme (Contract QLK4-CT2001-00423), the Academy of Finland (FINE-contract 201701), and the Centre of Excellence Programme 2002-2007 of the Academy of Finland (Contract 53307) and the National Technology Fund (TEKES, Contract 40715/01) and it belongs to the COST Action 633 "Particulate matter: properties related to health effects". The authors are grateful to the teams of T. Kuhlbusch (Institut für Energie- und Umwelttechnik, Duisburg, DE), M. Branis (Charles University in Prague, CZ), B. Brunekreef (University of Utrecht, NL), J. Sunyer (Institut Municipal d'Investigaci Mèdica, Barcelona, ES), and K. Katsouyanni and I. Kavouras (National and Kapodistrian University of Athens and National Observatory of Athens, GR), for conducting the sampling campaigns. R. E. van Grieken and Z. Spolnik (University of Antwerp, BE) are acknowledged for the ED-XRF analysis.

Edited by: R. Hitzenberger

\section{References}

Bardouki, H., Liakakou, H., Economou, C., Sciare, J., Smolík, J., Ždímal, V., Eleftheriadis, K., Lazaridis, M., Dye, C., and Mihalopoulos, N.: Chemical composition of size-resolved atmospheric aerosols in the eastern Mediterranean during summer and winter, Atmos. Environ., 37, 195-208, 2003.

Cachier, H., Brémond, M. P., and Buat-Ménard, P.: Determination of atmospheric soot carbon with a simple thermal method, Tellus, 41B, 379-390, 1989.

Chow, J. C., Watson, J. G., Crow, D., Lowenthal, D. H., and Merrifield, T.: Comparison of IMPROVE and NIOSH carbon measurements, Aerosol Sci. Technol., 34, 23-34, 2001.

Heal, M. R., Hibbs, L. R., Agius, R. M., and Beverland, I. J.: Total and water-soluble trace metal content of urban background $\mathrm{PM}_{10}, \mathrm{PM}_{2.5}$ and black smoke in Edinburgh, UK, Atmos. Environ., 39, 1417-1430, 2005.

Kavouras, I. G., Koutrakis, P., Cereceda-Balic, F., and Oyola, P.: Source apportionment of $\mathrm{PM}_{10}$ and $\mathrm{PM}_{2.5}$ in five Chilean cities using factor analysis, J. Air Waste Manage. Assoc., 51, 451-464, 2001.

Kawamura, K. and Ikushima, K.: Seasonal changes in the distribution of dicarboxylic acids in the urban atmosphere, Environ. Sci. Technol., 27, 2227-2235, 1993.

Kirchstetter, T. W., Corrigan, C. E., and Novakov, T.: Laboratory and field investigation of the absorption of gaseous organic compounds onto quartz filters, Atmos. Environ., 35, 1663-1671, 2001.

Kukkonen, J., Salmi, T., Saari, H., Konttinen, M., and Kartastenpää, R.: Review of urban air quality in Finland, Boreal Environ. Res., 4, 55-65, 1999.

Lighty, J. S., Veranth, J. M., and Sarofim, A. F.: Combustion aerosols: factors governing their size and composition and im- plications to human health, J. Air Waste Manage. Assoc., 50, 1565-1618, 2000.

Lim, M. C. H., Ayoko, G. A., and Morawska, L.: Characterization of elemental and polycyclic aromatic hydrocarbon compositions of urban air in Brisbane, Atmos. Environ., 39, 463-476, 2005.

Liu, B. Y. H. and Pui, D. Y. H.: Aerosol sampling inlets and inhalable Particles, Atmos. Environ., 15, 589-600, 1981.

Loo, B. W. and Cork, C. P.: Development of high efficiency virtual Impactor, Aerosol Sci. Technol., 9, 167-176, 1988.

Metzger, K. B., Tolbert, P. E., Klein, M., Peel, J. L., Flanders, W. D., Todd, K., Mulholland, J. A., Ryan, P. B., and Frumkin, H.: Ambient air pollution and cardiovascular emergency department visits, Epidemiology, 15, 46-56, 2004.

Na, K., Sawant, A. A., Song, C., and Cocker III, D. R.: Primary and secondary carbonaceous species in the atmosphere of Western Riverside County, California, Atmos. Environ., 38, 1345-1355, 2004.

National Atmospheric Emissions Inventory (NAEI): UK emission of air pollutants 1970-2001, National Environmental Technology Centre, Abingdon, UK, available at: www.naei.org.uk, 2003.

Novakov, T. and Corrigan, C. E.: Cloud condensation nucleus activity of the organic component of biomass smoke particles, Geophys. Res. Lett., 23, 2141-2144, 1996.

Nunes, T. V. and Pio, C. A.: Carbonaceous aerosols in industrial and coastal atmospheres, Atmos. Environ., 27A, 1339-1446, 1993.

Pakkanen, T. A., Loukkola, K., Korhonen, C. H., Aurela, M., Mäkelä, T., Hillamo, R. E., Aarnio, P., Koskentalo, T., Kousa, A., and Maenhaut, W.: Sources and chemical composition of atmospheric fine and coarse particles in the Helsinki area, Atmos. Environ., 35, 5381-5391, 2001.

Putaud, J.-P., Raes, F., Van Dingenen, R., Brüggemann, E., Facchini, M.-C., Decesari, S., Fuzzi, S., Gehrig, R., Hüglin, C., Laj, P., Lobbeer, G., Maenhaut, W., Mihalopoulos, N., Müller, K., Querol, X., Rodriguez, S., Schneider, J., Spindler, G., ten Brink, H., Torseth, K., and Wiedensohler, A.: A European aerosol phenomenology - 2: chemical characteristics of particulate matter at kerbside, urban, rural and background sites in Europe, Atmos. Environ., 38, 2579-2595, 2004.

Querol, X., Alastuey, A., Ruiz, C. R., Artinano, B., Hansson, H. C., Harrison, R. M., Buringh, E., ten Brink, H. M., Lutz, M., Bruckmann, P., Straehl, P., and Schneider, J.: Speciation and origin of $\mathrm{PM}_{10}$ and $\mathrm{PM}_{2.5}$ in selected European cities, Atmos. Environ., 38, 6547-6555, 2004.

Rodríguez, S., Querol, X., Alastuey, A., and Plana, F.: Sources and processes affecting levels and composition of atmospheric aerosol in the western Mediterranean, J. Geophys. Res., 107(D24), 4777, doi:10.1029/2001JD001488, 2002.

Rogge, W. F., Mazurek, M. A., Hildemann, L. M., Cass, G. R., and Simoneit, B. R. T.: Quantification of urban organic aerosols at a molecular level: identification, abundance and seasonal variation, Atmos. Environ., 27A, 1309-1330, 1993.

Russell, L. M.: Aerosol organic-mass-to-organic-carbon ratio Measurements, Environ. Sci. Technol., 37, 2982-2987, 2003.

Salma, I., Chi, X., and Maenhaut, W.: Elemental and organic carbon in urban canyon and background environments in Budabest, Hungary, Atmos. Environ., 38, 27-36, 2004.

Sciare, J., Cachier, H., Oikonomou, K., Ausset, P., Srada-Estève, R., and Mihalopoulos, N.: Characterization of carbonaceous aerosols during the MINOS campaign in Crete, July-August 
2001: a multi-analytical approach, Atmos. Chem. Phys., 3, 1743-1757, 2003,

SRef-ID: 1680-7324/acp/2003-3-1743.

Seinfeld, J. H. and Pandis, S. N.: Atmospheric chemistry and physics: From air pollution to climate change, John Wiley, New York, 1998.

Sillanpää, M., Hillamo, R., Mäkelä, T., Pennanen, A. S., and Salonen, R. O.: Field and laboratory tests of a high volume cascade Impactor, J. Aerosol Sci. 34, 485-500, 2003.

Sillanpää, M., Saarikoski, S., Hillamo, R., Pennanen, A., Makkonen, U., Spolnik, Z., Van Grieken, R., Koskentalo, T., and Salonen, R. O.: Chemical composition, mass size distribution and source analysis of long-range transported wildfire smokes in Helsinki, Sci. Tot. Environ., 350, 119-135, 2005.

Simoneit, B. R. T., Schauer, J. J., Nolte, C. G., Oros, D. R., Elias, V. O., Fraser, M. P., Rogge, W. F. and Cass, G. R.: Levoglucosan, a tracer for cellulose in biomass burning and atmospheric particles, Atmos. Environ., 33, 173-182, 1999.

Song, X.-H., Polissar, A. V., and Hopke, P. K.: Sources of fine particle composition in the northeastern US, Atmos. Environ., 35, 5277-5286, 2001.
Turpin, B. J., Saxena, P., and Andrews, E.: Measuring and simulating particulate organics in the atmosphere: problems and prospects, Atmos. Environ., 34, 2983-3013, 2000.

Viidanoja, J., Sillanpää, M., Laakia, J., Kerminen, V.-M., Hillamo, R., Aarnio, P., and Koskentalo, T.: Organic and black carbon in $\mathrm{PM}_{2.5}$ and $\mathrm{PM}_{10}$ : 1 year of data from an urban site in Helsinki, Finland, Atmos. Environ., 36, 3183-3193, 2002.

World Health Organization (WHO): Health aspects of air pollution with particulate matter, ozone and nitrogen dioxide, Report on a WHO Working Group; Bonn, Germany, 13-15 January 2003, available at: www.euro.who.int/document/e79097.pdf, 2003.

Yao, X., Fang, M., Chan, C. K., Ho, K. F., and Lee, S. C.: Characterization of dicarboxylic acids in $\mathrm{PM}_{2.5}$ in Hong Kong, Atmos. Environ., 38, 963-970, 2004.

Yu, J. Z., Xu, J., and Yang, H.: Charring characteristics of atmospheric organic particulate matter in thermal analysis, Environ. Sci. Technol., 36, 754-761, 2002. 